\title{
A TÉCNICA COMO HORIZONTE, A EXPERIÊNCIA ESTÉTICA E A HIPERMÍDIA
}

\author{
The technique as the horizon, the aesthetic experience and hypermedia
}

\section{Técnica como el horizonte, la experiencia y la estética Hipermedia}

Sérgio Bairon ${ }^{1}$

\section{Resumo}

O presente artigo analisa a relação entre a dimensão conceitual da técnica como horizonte e a dimensão comunicativa da experiência estética em sua expressividade hipermidiática. A análise baseia-se em princípios hermenêutico-fenomenológicos e propõe uma leitura particular da dimensão técnica da hipermídia, como uma nova forma de manifestação da compreensão. A técnica como horizonte é compreendida como a possibilidade do alcance do nível da reflexão analítica por parte da linguagem hipermidiática. O privilégio da pergunta à pergunta, à busca, ao estranhamento e à multiplicidade de respostas, são algumas das características desta nova forma de compreensão.

Palavras chave: Hipermídia, Técnica Como Horizonte, Comunicação E Experiência Estética

\begin{abstract}
The present paper analyzes the relationship between the conceptual dimension of technique as horizon and the communicative dimension of the aesthetic experience in its hypermediatic expressivity. This analysis is based in hermeneuticphenomenological principles, and proposes a particular view of the technical dimension of hypermedia, as a new form of manifestation of understanding. The technique as horizon is understood as the possibility of reaching the level of analytic reflection by means of hypermedia language. The privilege the question have to
\end{abstract}

\footnotetext{
${ }^{1}$ Livre-docente em Ciências da Comunicação pela ECA USP. Pesquisador bolsista produtividade 2 do CNPq. Pós-doutor pela Freie de Berlim, Alemanha. Doutor em Ciências pela FFLCH - USP. Historiador e Cientista Social. Líder do CEDIPP - Centro de Estudos e Produção Partilhada. Professor da ECA USP junto ao PPGCOM e ao curso de Publicidade. sbairon@ gmail.com
} 
question, to search, to estrangement, and to the multiplicity of answers, is some of the traits of this new form of understanding.

Keywords: Hypermedia, Technique As Horizon, Communication And Aesthetical Experience

\section{Resumen}

Este trabajo analiza la relación entre el tamaño del horizonte técnico y conceptual y la dimensión comunicativa de la experiencia estética en su expresividad hipermedia. El análisis se basa en los principios de la hermenéutica fenomenológica y propone una lectura particular de la dimensión técnica de hipermedia como una nueva manifestación de la comprensión. La técnica se entiende como el horizonte como la posibilidad de alcanzar el nivel de la reflexión analítica sobre la parte del lenguaje hipermedia. El privilegio de la cuestión a la pregunta, a la búsqueda, el distanciamiento y la multitud de respuestas, son algunas de las características de este nuevo entendimiento.

Palabras clave: Hipermedia, Horizonte Técnico, La Comunicación Y La Experiencia Estética

A hermenêutica busca caminhos alternativos nos quais a experiência estética deve possibilitar a autocompreensão das manifestações da historicidade dos fenômenos. Nesse sentido, a essência da experiência estética não é uma atualização transitória que manifesta uma pura consciência histórica, mas a manifestação de um ser que se atualiza recorrendo historicamente a si mesmo. Portanto, é fundamental não criarmos sobre a experiência estética nenhuma perspectiva que pretenda a imediatez da classificação científico-positivista, mas que aborde a historicidade dialógica de todo processo de compreensão (Heidegger, 1952).

Parto do princípio de que no universo da experiência estética, a imagem participa diretamente da essência da compreensão, pois tudo aquilo que está expresso volta-se a si mesmo, ou seja, está por si mesmo em sua imagem (Burdea \& Coiffet, 1996). É por essa brecha que começamos a enxergar a relação inevitável entre a nãolinearidade e a experiência estética. A partir daí percebe-se que todo autor de hipermídia deve procurar, a todo custo, o caminho da experiência estética sob o ponto de vista de uni-lo com a técnica. $\mathrm{O}$ autor de hipermídia, justamente porque o 
"leitor" estará na mesma situação, deve dar vazão às suas casualidades com o material que está produzindo; deve exercitar tais irrupções, acima do todo da verdade metodológica à direção da valorização de uma experiência estética com o conceito teórico. Disso brota uma historicidade mais conseqüente em discernimentos científicos, estéticos e filosóficos: uma consciência histórica efetiva (Gadamer, 1991).

Mas como chegar lá? Acredito que a estética deve subsumir na hermenêutica e na semiótica, ou seja, deve retirar destas suas principais premissas à caminho da compreensão de um determinado fenômeno. A compreensão deve mostrar-se como fragmento de um sentido que se constrói em todo enunciado, isso tanto na experiência estética como na ciência ou na filosofia. Comentando o processo de fecundação sígnica, Santaella diz:

“(...) artistas e cientistas são aqueles que encontram vias para flagrar, dar corpo, coisificar essas instâncias - instantes naquilo que chamamos suas grandes descobertas: ícones da sensibilidade que aspira a ser inteligivel (arte) e ícones da intelecção que aspira a ser sensível (ciência)”. (Santaella, 1989: 31).

O encontro do sensível com a intelecção a que se refere Santaella está na busca que podemos deflagrar por um sistema hipermídia como comunicação integrada. Para a hermenêutica, por exemplo, as discussões em torno do prejuízo levam à questão da antecipação do sentido e à da circularidade da compreensão, fundamentos que tenho defendido como bases essenciais da não-linearidade. Como vimos, subjacente a tais discussões está a idéia de que as partes que delimitam o todo adquirem sentido somente a partir desse todo, mas que todos os sentidos daí emergentes estão em "eterna" mutação sígnica, como no jogo infinito das fractais (Mandelbrot, 1977). A virtualidade da hipermídia, fruto desse movimento, está na ampliação das unidades de sentido, compreendidas em círculos concêntricos e na conquista, por meio disso, da congruência de cada detalhe com o todo (Darley, 2002). É importante entendermos que a antecipação de sentido que guia a compreensão na hipermídia não é um simples resultado da subjetividade, mas revelase a partir da comunidade que nos une com determinada tradição conceitual. A circularidade da compreensão não é um círculo metodológico, mas descreve um momento estrutural da própria compreensão. Compreender é entender-se na técnica como horizonte. (Bairon \& Petry, 2000) 
Na hipermídia que se apresenta também como experiência estética, a verdade começa ali, no momento em que algo nos interpela e sua exigência pode colocar completamente em suspenso os próprios prejuízos. Na técnica como horizonte, a totalidade da suspensão de todo prejuízo ocorre diante da pergunta que tem como essência o abrir-se e manter-se aberta às mais variadas respostas. Portanto, a experiência estética com a hipermídia é um profundo exercício palinódico: “ $A$ experiência é, pois, experiência da finitude humana" (Bairon \& Petry, 2000: conceito verdade). $\mathrm{O}$ ser que a experimenta evidencia-se como aquele que conhece seus limites com as palavras, não se pretendendo dono do tempo. É a própria historicidade que delimita a verdadeira experiência no interior de toda busca. Navegar evitando a pergunta é colocar a comunicação numa função instrumental e metodológica, já que situar-se na pergunta não implica estar limitando a própria liberdade do conhecer, mas, ao contrário, é justamente a essência de toda possibilidade de conhecimento. E questão da relação entre o perguntar e a experiência estética é essencial na obra magna de Gadamer "Verdade e Método" (Gadamer, 1975-1988).

Portanto, voltemos à questão da pergunta. Uma das primazias da técnica como horizonte está enraizada na estrutura da pergunta, justamente porque não podemos escapar da incompletude que nos cerca e nos define a partir de nós mesmos. Perguntar deve significar suspender todos os prós e contras. É a principal maneira de alguém estar ao mesmo tempo contra e a favor. É aqui que a técnica como técnica exibe suas limitações estruturais no âmbito de consciência histórica efetiva: não há método linear que acompanhe o perguntar, pois todo perguntar pressupõe um saber que não se sabe (Hillis, 1999). Há um não-sentido e uma não-linearidade que conduzem à pergunta. Como no movimento dialógico, entre pergunta e resposta, o assistente da hipermídia pode aprender que a grande experiência da compreensão não está somente no ganhar, conclusivamente, o conhecimento dos fatos (Mackay \& O’Sullivan, 1999).

Na estrutura digital não devemos ver no signo lingüístico um instrumento de uso, mas o modo de ser da comunicação, que mesclada ao ser, faz uso dos sentidos como se estivéssemos num eterno ato de perguntar. Toda palavra, portanto, é já sentido dependente da fusão técnico-horizôntica. Se o signo, numa visão econômica, é o resultado da unidade que a tradição promove entre palavra e coisa, conforme 
aprendemos com a semiótica, ele jamais pode estar vinculado somente ao seu estatuto simbólico (Santaella, 2001). Na rede de significações, que de fato pode estar disponível numa hipermídia, localiza-se o estatuto revolucionário dessas mídias digitais. Ficará cada vez mais difícil escaparmos dessa tradição da valorização da diversidade de sentido da palavra. Não se trata de tentar superar a deficiência da multiplicidade de sentido dos signos, ao contrário:

“(...) justamente porque nosso intelecto é imperfeito, isto é, não se é inteiramente presente a si mesmo naquilo que se sabe, é que temos necessidade de muitas palavras. Não sabemos realmente o que sabemos" (Gadamer, 1975: 65).

Ao penetrar no horizonte da hipermídia, o intérprete não deve exercitar o abandono de seu próprio mundo, mesmo que metodologicamente assim o deseje. $\mathrm{O}$ universo sígnico não é unicamente o resultado de seu pensamento reflexivo, mas sua realização no mundo, por isso dizemos que em todo universo sígnico o mundo se auto-representa. Isso nos leva a concluir que o mundo não pode ser objeto da linguagem, muito menos da técnica. A leitura da objetividade presente em toda técnica adapta toda sua determinação volitiva à idéia do mundo em si, tentando criar independência frente a todo sonho do sujeito. É preciso, acima de tudo, garantir o saber-fazer metodológico; tal como a mecânica, a técnica como horizonte orienta-se também ao poder fazer. Apesar de a mecânica investigar o que é, como deve ser ou como funciona, ela, assim como a biologia ou a física, não pode ser o que investiga. Ou seja, aprendemos com a semiótica peirceana que mesmo a validade da ciência exata não tem a mesma objetividade daquilo que ela investiga. $\mathrm{O}$ mundo que permeia a técnica não pode ser em si, ou até relativo, da mesma forma que podem ser os “objetos” que a técnica manipula (Heidegger, 1952). As manifestações estéticas sabem disso e assim se manifestam. Representam em seus fragmentos o mundo em que estão incutidas e em que são faladas como um todo (o todo da poesia, não a linearidade metodológica do todo).

A técnica como horizonte, não pode ser em si, não pode ser compreendida em seu ser-no-mundo metodologicamente. Os juízos estéticos que cercam a técnica como horizonte, devem ser os mesmos a manifestar sua historicidade palinódica, tendo como juízo fundamental o fato de que o universo sígnico revela a essência histórica de nossa finitude. Tal princípio vale tanto para a essência, quanto para a 
experiência na ciência e na estética. $\mathrm{O}$ assistente hipermidiático pode perceber a legitimidade da experiência da consciência histórica efetiva por ele vivida, procurando, assim, revelar a verdade de seus sentidos, sem que isso ocorra em detrimento da ação de seus prejuízos. É assim que poderá aproximar sua compreensão objetiva não-linear de uma manifestação estética (Bairon \& Petry, 2000).

A estética, no caminho da técnica como horizonte, quando evidenciada pelo cotidiano, percorre o traçado das discussões sobre o belo enquanto equilíbrio. A medida pitagórico-platônica vê no belo a adequação à proporcionalidade; Aristóteles vê como principais características do belo a ordenação e a determinação matemática. Porém, voltar nossos olhos a Platão, em sua relação do belo com a luz, pode nos fazer entender que a forma de ser da beleza é a própria luz. Sem luz nada pode ser belo, questão entendida pelo próprio Santo Agostinho, ao destacar que a luz que revela é a luz da palavra: "Deus só fala pela primeira vez ao criar a luz." (in: Gadamer, 1975: p.504). No entanto, sem sombra, não temos luz. De Platão a Santo Agostinho a multiplicidade de sentido ocorre pela unidade da palavra e foi nessa tradição de valorização da linguagem, em suas multiformas, que se inseriu historicamente a hermenêutica.

A compreensão não depende de um virtuosismo técnico e, sim, da experiência estética com o fenômeno que vale como verdade. A conceituação fenomenológica de coisa nos leva à essência da compreensão histórica frente ao seu mundo: que não haja nenhuma coisa, ali onde falte o signo. Porém, só pelo emprego da palavra, não se apresenta disponível tudo o que está para ser contemplado, mas o que está aí para ser compreendido pode tornar-se presente pelo dito, “assim como a idéia de belo está presente no que é belo" (Gadamer, 1975, p.340). A expressão poética representa toda entrada na comunicação à caminho da descoberta da própria comunicação. Qualquer objetividade de conhecimento linear, parte do princípio de que a historicidade é passível de lógica interna e, mais que isso, tende a anular os fenômenos da casualidade e da dispersão, tão importantes à compreensão. Se a valorização da casualidade parte do princípio de que o modo de ser da técnica como horizonte, no interior de uma hipermídia, é o desenvolver de suas imprevisibilidades, evidentemente que um autor/assistente na hipermídia só pode procurar o sentido do passado por meio das revelações que a própria hipermídia oferece: 
A produtiva plurivocidade em que consiste a essência da obra de arte não é mais que outra maneira de expressar a determinação essencial do jogo, que é converterse cada vez num acontecimento novo. Nesse sentido fundamental, a compreensão das ciências humanas se situa na mais estreita proximidade com a experiência imediata da obra de arte." (Gadamer, 1975: 340)

O próprio título da obra magna de Hans Georg Gadamer, Verdade e método, já procurava apresentar a clássica tensão criada pela metodologia científica, dos últimos séculos, entre verdade e método científico. O método iluminista, ao tentar construir o caminho à verdade, tende a negar a possibilidade da abertura hermenêutica ao caminho da compreensão horizôntica. Portanto, os conhecimentos e valores de cada autor/assistente da hipermídia não devem servir como objeção à cientificidade de sua verdade, assim como os valores e conhecimentos do autor de uma obra de arte não servem de limitação às suas verdades reveladas. Ou seja: não devemos esquecer que no interior de uma criação em hipermidiática todo experimento técnico faz parte de uma semiose ilimitada. A ciência, ou mesmo a técnica, não podem anular tal processo, como foi pensado no Iluminismo. (Gadamer, 1975-1988)

A reflexão emancipadora do Iluminismo pressupõe, inevitavelmente, a coesão dos fatores da objetividade: um sujeito tem condições de apreender o objeto em totalidade. Sua coerência temática, muitas vezes pressupõe unidade de sentido. Na hipermídia como experiência estética, a estrutura de hiperlinks pode facilitar a expressão da multiplicidade de vozes, inclusive no meio acadêmico, desde que esteja construída com base em relações conceituais dialógicas. Toda reflexão poderá, se quisermos, manter-se aberta às críticas, daí sua relação com o mundo palinódico da expressividade digital da compreensão, pois tudo que pode ser submetido a uma reflexão, já vem limitado pelas marcas de prejuízos preestabelecidos, mas não primordialmente objetivos:

"O que eu tenho descrito como fusão de horizontes é a maneira como se realiza a unidade de um sentido, que não permite ao intérprete falar de um sentido original de uma obra, sem se ter introduzido, na compreensão da mesma, o sentido próprio do intérprete." (Gadamer, 1975: 234) 
As rupturas com a fusão de horizontes, propostas pela metodologia iluminista, tendem a esconder a abertura ao mundo da semiose, não reconhecendo que temos limitações ontológicas para sermos objetos de nós mesmos.

Se a compreensão não é o resultado da eficácia metodológica de interpretar outra pessoa, outra época, outra situação, outra cultura etc., mas é o poder que o ser tem de compreender as possibilidades de ser de cada um no mundo, compreender o outro a partir da compreensão da unidade do seu ser, independente do seu mundo, não é possível. Tudo isto equivale a dizer que para um assistente/autor de hipermídia, tentar conceber o mundo de sua compreensão, passando separado de si próprio, deve ser encarado como um processo solipsista, independente da estrutura midiática utilizada. Estar no mundo é viver na anterioridade da relação sujeito/objeto, portanto, é viver na antecipação de qualquer objetividade ou subjetividade. A relação sujeito/objeto, tão aclamada pela metodologia iluminista, tende a ver a expressão da compreensão como algo que é o mundo e não como algo que está no mundo (Heidegger, 1985).

É aqui que podemos constatar os sentidos mais relevantes das críticas à metodologia iluminista de apologia metodológica da linearidade. O tema da estética na ação da técnica como horizonte, deve afastar a noção de criação do axioma clássico do sujeito do conhecimento. Na hipermídia não podemos considerar a experiência estética um mero objeto de prazer, pois deve ser muito mais que isso: um evento da manifestação da verdade do ser. É por isso que podemos dizer que a experiência estética está extremamente próxima da experiência científica. Sendo a experiência estética, ao contrário do instrumento, irredutível ao mundo, ela própria abre e funda um mundo; ela não pode simplesmente estar no mundo, pois provoca profundas mudanças no ser. (Heidegger, 1985)

A origem da obra de arte é a própria arte. A realização da arte está na própria obra, pois nas obras de arte temos muitas maneiras de compreender o cóisico. Mas, geralmente, temos forçado a obra a entrar num preconceito que obstrui qualquer acesso ao ser, pois os conceitos que usualmente estão presentes para entender o cóisico, não nos proporcionam tal acesso. O que a experiência com uma obra de arte revela é que a verdade não é só a propriedade do conhecimento que se anuncia, mas a propriedade do ser mesmo. Na tradição cartesiano-iluminista, a verdade, contrário à época do filósofo grego Parmênides, é sinônimo de autenticidade, pois o ente só é 
verdadeiro se se apresentar tal qual é. Parodiando Heidegger, podemos dizer que, quando uma verdade vai além do correto e da precisão, atinge o essencial deslumbramento do ente enquanto tal e torna-se esperiência estética (Heidegger, 1952).

Venho defendendo a idéia, que o acontecer da questão central que delimita a forma de ser da técnica como horizonte na Hipermídia, está localizado na construção de ambientes gráficos que sejam mundos de acesso aos conceitos com os quais estamos trabalhando. Isto pressupõe um projeto que encampe a imagem não mais como referência de algo, mas como ambiente conceitual. Ao entrarmos na hipermídia como experiência estética, não estamos simplesmente penetrando na construção de telas que não tenham nenhuma relação com as idéias ali propagadas, pois as imagens pressupõem um diálogo com a verdade sob o ponto de vista essencial (Turkle, 1997 e Hansen, 2000).

Apesar da experiência estética ter perdido a aura identificada pela análise de Walter Benjamin, em seu artigo consagrado, acredito que estejamos no limiar do nascimento de uma reprodução que diminua a distância entre a experiência estética e a compreensão científica, entre a consciência e a historicidade. Mesmo os fractais de Mandelbrot (Mandelbrot, 1977) já revelavam não só a irregularidade da realidade que se apresenta contrária a qualquer modelização homogênea, mas, também, a essência da descrição da técnica como horizonte no interior de um roteiro hipermidiático reticular. A dimensão fractal, ao contrário das dimensões euclidianas, relaciona as irregularidades, fruto da fragmentação imagética, com o fenômeno da reprodução tanto na natureza quanto na arte; tal como a reprodução da imagem na obra de Arcimboldo, pode nos levar à decomposição de cada objeto enquanto condição sine qua non à compreensão (Thames and Hudson, 1987).

Compreender o barroco sem fragmentar o objeto é impossível. Da mesma forma, a técnica como horizonte de compreensão, expressa-se conjugando contradições clássicas: por ser não-linear, todo sentido se evidencia, não a priori, mas a partir de seu uso; pode estar coerente, em concomitância com a imprevisibilidade e a regularidade; apresenta-se em dimensões que podem ser contraditórias em nível de conteúdo; nela, a viariação não é incompatível com a similaridade. 
$\mathrm{Na}$ estrutura da técnica como horizonte, o universo de revelações artísticas pode explicitar o fato de a essência da arte não se expressar como a atualização de uma consciência histórica, mas, sim, como meio pelo qual mais conseqüentemente o ser se atualiza pela recorrência a si próprio. A identidade, nesse ambiente, só pode ocorrer na recorrência a sua estrutura dialógica. A evidência que se expõe a partir dessa estrutura, situa o ser na incompletude do mundo, maneira de ser da própria experiência estética; assim, a experiência esta define método como caminho de autorepresentação, produzindo universalidades imersivas contando com o repertório de quem navega. O universal não é fruto de uma taxionomia, mas do modo de ser da experiência estética em sua abertua ao mundo da compreensão, da flexibilidade conceitual e da auto-representação. Ou seja, o fato de realçar a potencialidade da experiência estética não está no ato de a nomearmos como tal, mas, sim, é proporcional às transformações que ela provoca em todos nós (Heim, 1998).

A técnica na hipermídia pode se aproximar do ato de desapropriação do significado pela valorização da polifonia e do multilingüismo do sentido. Vídeos, animações, efeitos de áudio, etc, mesclam-se na construção de caminhos e de ambientações que possibilitam a perda dos limites institucionais da arte em prol de sua vitória no cotidiano (McLuhan, 1998). Deste hibridismo midiático podemos encontrar o estético no sentido comum, assim como podemos encontrar o científico na arte. Há uma estética iluminista que pretende julgar o belo por meio de sua aproximação com a natureza, o que só pode ser feito pelo gênio. Agora, com a possibilidade do domínio do estético pelo senso comum, o gênio não apresenta-se mais como o único referencial do gosto estético, não é mais responsável pelo sentimento vital que gera a imaginação ou a compreensão do que é belo. No interior de um sistema hipermidiático que explore a técnica como horizonte, não existem mais belas-artes enquanto dote do gênio, nem mesmo o processo estético como o resultado de um caminho totalmente subjetivo em sensibilidades, pois o ser do mundo "em si" da experiência estética, pode se encontrar na expressividade mais simples do senso comum. Devemos relutar a idéia de que a revelação de toda compreensão estética só pode ocorrer pela classificação acadêmica e/ou pelas particularidades de ambientes artísticos (Bairon \& Ribeiro, 2007). 
A técnica como horizonte revela, literalmente, que a soma do inacabado com o não-sentido reúne vários elementos que no agir de toda compreensão, tanto de quem cria o sistema quanto daquele que o utiliza, se instaura a incompletude.

"A representação da arte implica essencialmente que se realize para alguém, ainda que não haja ninguém para escutá-la ou vê-la." (Gadamer, 1975: 535)

A técnica como horizonte une humildemente cotidiano e vanguarda. A memória que se constrói pela sua navegação está muito mais próxima do imaginário fruto da ação da rede de significantes do que da tentativa de classificação sistemática da compreensão. Nesse meio, habitamos como habitamos uma casa: com imagens, sons, diálogos, caminhadas, numa freqüente interação com as coisas que ali colocamos e que nos interpelam. No entanto, não podemos esquecer a familiaridade com os objetos é uma construção e não algo dado. O contraponto da técnica nesse contexto não está localizado nas contradições histórico-sociais, mas na ação do ser frente a suas possibilidades de auto-reconhecimento. A construção, a fabricação e o uso de um ambiente interativo podem, tanto estar comprometidos pela técnica como revelados e possibilitados por ela. Nesse meio, a liberdade de criação hipermidiática deve procurar explorar, no mínimo, em igual intensidade, a liberdade de interpretação e a compreensão de seu conteúdo. Poderemos alcançar, assim, a noção de que o ser não só é o tempo de sua dedicação para com a compreensão, como, também, o resultado infinito da ação da incompletude do sentido. A incompletude, que está sempre presente em toda compreensão, demonstra a diversidade da estranheza do ser consigo mesmo e da estranheza fruto do uso com os 'objetos' que o cercam. Numa frenqüente relação dialógica com o todo e a parte, vamos construindo a historicidade da compreensão (Landow \& Delany, 1991).

A técnica, enquanto horizonte provável, não contém forma nem conteúdo, bem como não intenciona ilustrar o mundo, mas oferece um espaço hipermidiático para os conceitos se auto-revelarem. Trara-se de oferecer àquele que a experimenta a chance de se ver transformado por ela, pois está sintetizada no surgimento de um sentido, como se ele sempre tivesse existido sem ser descoberto até então. A falta da palavra não significa ausência de interpretação e todo horizonte de navegação é apenas um convite a nossa presença. Nossa presença vai se construindo pela fusão de horizontes que são alçados segundo o trajeto determinado pela busca. Nesse 
desdobrar do sentido estamos partilhando nossa busca com os caminhos que se reapresentam a nós, e nossa consciência desse caminho se revela muito mais no caminhar do que no modo de ser de uma consciência que alcança seu limiar. A maneira de ser do jogo da pergunta e da resposta, cria um estado de freqüente especulação que intenciona saciar, a cada nova pergunta, toda finitude circunstancial. A verdade aparece como condição de sua própria negação, um legítimo evento de desvinculações entre projeções e historicidade. Imersos nesse meio, podemos vivenciar literalmente o vínculo entre nossa identidade e boa parte do mundo que a cerca.

Pode-se dizer: sem a linguagem não podemos nos comunicar? Isso soa como se houvesse comunicação sem linguagem. Porém o conceito de linguagem repousa sobre o conceito mesmo de comunicação" (Wittgenstein, 1987: 89)

Portanto, quando associado ao rico mundo da produção de ambientes digitais de navegação, o mundo do domínio técnico dos softwares gráficos e de autoria, pode transformar aquele que cria em arquiteto de conceitos. Alguns autores já se referiram ao mundo da hipermídia como uma linguagem que se aproxima do resultado da estrutura barroca. Calabrese (1989), por exemplo, lembrou que o mundo digital, com suas peripécias mutantes e abundantes, causará uma retomada de temas da arquitetura barroca. Letras animadas, estrutura não-linear, abundância sígnica, uma grande quantidade de informação, a palinódia e a metáfora são algumas das características que, sem dúvida, podem aproximar esses dois mundos.

O Barroco causa isto: perdendo a unicidade de sentido, toda historicidade que se revela a partir daí é resultado, sempre, da união de ruínas, de restos. Uma espécie de mescla entre as noções de ruína de um Buckhardt e Walter Benjamin. A restauração nunca é do sentido, mas, sempre, de um sentido que nunca existiu. É a Fênix ressurgindo das próprias cinzas, ou seja, é a alegoria em suas manifestações fragmentadas. Na reabilitação benjaminiana da alegoria não existe possibilidade de manifestação de sentido sem que tenhamos o desmembramento. Há algo de essencial na alegoria: a transmutação. Congelar as representações de estrutura matemática do mundo digital, é reduzi-lo ao eterno, em detrimento do efêmero. Portanto, o som, a imagem, a passagem e o ambiente no mundo digital antes que se apresentem tal qual, são linguagens. Como um dia já disse Quéau: 
As linguagens formais nos 'resistem' e contêm mais coisas do que acreditamos ver nelas. As matemáticas possuem uma vida estranha que fascina e surpreende os melhores matemáticos. (...) O artista de amanhã será, sem dúvida, chamado a utilizar a autonomia desses 'seres' intermediários como novo meio de expressão, $e$ poderá tirar partido de sua vida artificial para criar obras em constante gênese, processos quase vivos, modificando-se sem cessar eles mesmos em função do contexto." (Quéau, 1996: 45)

Próximos à melancolia barroca, imergimos na maré do palinódico e começamos a trilhar um longo caminho na convivência com o desdito. Noutro momento tive a oportunidade de destacar esse encontro com a modernidade digital, em que o instante aristotélico e o agora hegeliano destruiram-se mutuamente no interior da concepção monadológica de Walter Benjamin. O agora (jetztzeit) de Benjamin apresenta-se como toda ação presente que emerge do cotidiano em seu caráter antecipado de futuro/passado. O tempo do agora é um recolhedor de experiências, de relatos utópicos e, tal como uma falsa memória, alimenta-se da repetição do não realizável (Benjamin, 1977).

Na técnica como horizonte, tal como no barroco, a descoberta do sujeito que contempla a compreensão só se torna possível graças à concomitância da morte/renascimento dos objetos e dos sentidos. Nesse ambiente, a ruína passa a ser regra, uma vez que toda construção imagética baseia-se em formulações matemáticas que carregam sobre si a necessidade de renovação e a necessidade de reconstrução da obra. Gadamer nos lembra que na direção semântica da palavra 'obra' encontramos a palavra técnica, téchne. Não quer ressaltar, prioritariamente, o fazer ou o produzir, mas, sim, a capacidade espiritual de plenajar, criar, buscar, sintetizada no saber daquele que faz e que constrói, o érgon. (Gadamer, 1991) Por um lado, aqui vale salientar que todo produto criado pela hipermídia não tem nenhuma validade em si, além do uso para o qual está destinado. Por outro lado, o conceito de estética associado somente à arte é algo que não atende à pergunta sobre o porquê de sua existência. Por mais contraditório que pareça, é no encontro desses dois lados que os horizontes conceituais deverão atuar na hipermídia, que se digne interativa e fruto do encontro entre ciência e arte. Gadamer inspira-se na mimese platônica, em que temos não só a promoção do encontro entre imitação e imitado, mas também na produção de uma verdade que se define como resultado da relação entre conhecimento e reconhecimento. Compreendemos, porque muito já tínhamos compreendido. É daí 
que a verdade, a partir da experiência estética, seja algo que emerge e irrompe como compreensão, e não como fruto daquilo sobre o que refletimos (Heidegger, 1952).

O que tenho procurado esclarecer é que na técnica como horizonte, a irrupção da verdade se dá pela revelação não de idéias, mas de ambientes, de moradas em que a priori, as coisas emergem, sem que sua principal ontologia esteja numa seqüência de aparecimento ao mundo. Nesse contexto, a linguagem deve assumir sua condição de expressividade poética à busca da experiência. Esta pertença ao mundo não se revela em sua atuação ou produção, mas, sim, no acontecimento da abertura de novos horizontes a cada nova compreensão. Na navegação não vivencio um mundo que está ou não presente na hipermídia, mas a relação de meus horizontes com os horizontes que se apresentam a mim. Mais que o acontecer de uma simples interpretação, tratase de uma tecnologia que trabalha com a possibilidade de respeitar o tempo da espera, que pacientemente se coloca à disposição da compreensão ou da emergência de um sentido. Esperar, demorar e refletir não são perda de tempo, ao contrário, trata-se da superlativização da surra que a leitura dá na televisão. Enquanto a primeira respeita o ritmo de cada um, a televisão tradicional atropela a compreensão, pois não dá tempo a qualquer respiração e nos impõe seu discurso (Levy, 1999). Demorar para compreender é fruto do desdobramento de uma relação dialógica que não tem prazo para terminar, pois seu sentido cronos primeiro, é durar até que seja levado ao seu fim.

Mesmo com a emergência da compreensão não se trata, prioritariamente, de perguntar pelo significado de cada passo na hipermídia, segundo as intenções da equipe criadora, nem de exigir de mim mesmo uma compreensão única enquanto receptor. Trata-se da morte do receptor no interior do reconhecimento da transformação de horizontes que se entrecruzam na suspensão de todo ato de opinar.

Devemos nos acostumar com a idéia de que o sentido não emerge de uma situação de contemplação frente a falta, mas multiplica-se na continuidade da busca que anula tanto o inaugural quanto o constituinte. Temos a chance de oferecer o exercício da condição movediça da linguagem, contrária à qualquer fixidez de significado. A cada novo sentido, surge uma nova configuração de horizonte que nos convida a experimentar a própria variação. O provisório se transforma em efetivo e, assim, toda efetividade só sobrevive na efemeridade. Tal como o mundo se apresenta a nós, a experiência nos absorve, nos envolve, nos encasula, literalmente. A 
mensagem se dilui na contradição de vozes, imagens e sons. A mensagem está freqüentemente em perigo. Um sentido, a qualquer hora, pode perder o rumo, desaparecer e nunca mais voltar. Assim como pode retornar repentinamente, como aquele Foucault do pêndulo foi manifestado por Eco, ou como o Shakespeare resgatado pelo Sturm und Drang (Auerbach, 1970). O caminho ou código não são mais os meios, ou vice-versa; o meio é o mundo, o sentido está dependente de sua dimensão palinódica, assim como aquelas experiências com a arte que nunca terminam de significar, que nunca cessam de se inscrever. O "óbvio", o "coerente", o que "tem sentido", o que "está claro" é o caminho de desbravamento dos horizontes. A técnica nesse universo se sente subjugada, domesticada pelo conceito, assim como o lápis que se entrega à mão. Cotidiano, sempre a melhor associação. Compreensão circular, perpendicular, oblíqüa, transversal, jamais linear, jamais de acordo com o objeto. O mundo com o qual agimos não se apresenta como simples soma dos objetos que nos cercam, como que numa descrição cognitiva de tradição analíticokantiana (Heidegger, 1985).

O mundo é a soma infinita de horizontes em que habitam as coisas e os seres, é a própria condição de existência do ser-aí, do estar-aí. Tal como o inconsciente freudiano-lacaniano, o mundo não pode ser um objeto analisável, não é redutível ao método. Sua experiência mais própria está na abertura, na busca, no desvelamento, na irredutibilidade à presença. Apenas de vez em quando nos é oferecida a experiência de ter uma intimidade com aquilo que se sustenta no ato de compreender algum fenômeno. Sentido é o que se constrói na abertura da compreensão, diz Heidegger. Há sempre uma visão prévia que possibilita que algo se torne compreensível como algo. Extensão do homem, sim, mas do homem no mundo (Heim, 1998).

McLuhan viu na eletricidade o corte na seqüência linear da palavra impressa. A simultaneidade da compreensão tornou-se possível, assim como o imaginário da criatividade se sobrepôs ao mundo das sequiências e dos encadeamentos lineares. Sem dúvida o tema dos meios de comunicação como extensão do humano nos possibilita pensar no encontro da compreensão da técnica como horizonte com a forma de ser reticular do estar no mundo de todo sentido. Novidade? Não, no âmbito conceitual; sim, nas possibilidades digitais do encontro da experiência estética com a técnica, num caminho que deve se desdobrar da primeira em direção à segunda. A 
experiência estética deve comandar essa extensão do homem na direção das manifestações digitais e responder à pergunta pela técnica por meio da linguagem hipermidiática (Bolter, 1991). Tratar a técnica como horizonte é refundar uma leitura da técnica que nunca pode buscar a evidência primordial de seus recursos, mas, sim, a relação entre suas potencialidades e seu lugar nos mais variados cotidianos. Portanto, a essência dessas novas tecnologias da comunicação, só pode apresentar-se como um conhecimento em si, numa narrativa fática, no contexto de evolução de programas e máquinas. Todo horizonte que se desdobra a partir daí é composto pelo universo conceitual-teórico, pelo qual optamos para tratar de questões de tecnologia. A essência da idéia da técnica como horizonte, implica que a compreensão que se manifesta nela deve explorar a possibilidade identitária de imersão em seu mundo. Deve explorar a idéia da construção de mundo. É uma compreensão que pretende desvelar a técnica pelo seu próprio desdobramento. A técnica como horizonte, enquanto possibilidade de oferecer uma compreensão fruto de manifestações hipermidiáticas, deve sempre ser determinada pelo seu próprio ser-no-mundo. Sua crítica ou sua análise, de alguma forma, sempre devem se colocar como autocrítica, sabendo, no entanto, que a plenitude nunca poderá ser alcançada (Bairon, 2000). É uma espécie de condenação da metodologia científica tradicional e uma ascensão do diálogo como valor principal.

A idéia dos programas como ferramentas revela o comércio do equipamento como utensílio. O problema básico de todo aquele que analisa as mídias digitais e não produz nelas, é que pretende adquirir um saber das coisas anterior ao seu uso. Justamente por ser 'somente' um utensílio é que a potencialidade do mundo dos programas interativos só pode aparecer pelo seu manuseio. O intra-mundano está no uso, nunca na ferramenta. Como podemos falar da importância do metrônomo para a música se não entendermos nada de música e, nem mesmo, do utensílio? Como poderemos avaliar as mudanças e potencialidades que tal ferramenta trouxe? Poderemos, quiçá, analisar resultados, mas jamais suas potencialidades. Se, de alguma forma, não nos tornamos mestres frente ao utensílio, esse passa a nos atingir animicamente. $\mathrm{O}$ uso é a forma mais primitiva de acesso à compreensão do mundo, que se apresenta a nós por meio das ferramentas que presentes no cotidiano.

O tornar-se cotidiano, significa tornar-se desapercebido como novo ou revolucionário. Significa estar em casa, apesar de todo estranhamento. A partir desse 
momento passamos a produzir uma pré-compreensão que nos guia no ato criativo. É mais ou menos como o fato de que o analfabeto jamais se tornaria um grande escritor, pois não bastaria ditar uma história que seria posteriormente escrita: faltalhe o exercício técnico-criativo da escrita, que só desenvolvemos pelo exercício da própria escrita (Olson, 1998). É por meio desse comércio entre o domínio técnicometodológico e a criação, que consagramos por completo o instrumento. Assim, nos apropriamos não do ser útil como tal, mas da compreensão que emerge daí. Isso significa que a compreensão é um dar-se prévio frente ao uso e sua potencialidade.

O exercício da técnica como horizonte provável apresenta uma dimensão que capacita o pré-tematizado como elemento fundamental da pré-compreensão. É na pré-compreensão que deve residir a essência da técnica que, tendo a colaboração do conceito existencial de téchne, nos apresenta o conhecer como obra, produção e criação. Ou seja, o conhecer se revela resultado de uma ação pragmática da téchne. Nesse sentido, o maior desafio concentra-se na transposição da criação e da reflexão analítica ao mundo técnico de estrutura digital (Hansen, 2004). A mundo digital nos oferece essa possibilidade de uso das coisas, no interior do qual a técnica deve sumir, em prol do nascimento de um ente que advenha da manipulação do objeto virtual, evitando que a técnica se justifique no caminho semântico do algo como algo. Em plena inauguração de um novo mundo conceitual, a técnica como horizonte provoca um rol de problematizações filosóficas, exatamente a partir de seu uso na dimensão estética. Esse momento é o que chamo de autofundação da tecnologia digital. A autofundação da técnica como horizonte necessita se estruturar em equipe. Mas não qualquer equipe, nem mesmo uma equipe somente artística ou somente conceitual, mas, sim, composta por sujeitos que tenham uma grande familiaridade tanto com a linguagem artística quanto com a linguagem conceitual em questão. A compreensão que guiará tais caminhos técnicos, assim, será o desdobramento de uma união entre as potencialidades das estruturas técnicas e a criatividade da equipe, agindo como que num resgate de uma compreensão pré-ontológica. Toda atividade técnica num projeto de construção conceitual abriga uma latência ontológica que pode ser identificada pela percepção do encontro entre sua fundação e sua condução. Esse encontro possibilita o equilíbrio entre o universal e o particular, pois evidencia-se que, concomitantemente, a partir do particular, toda a universalidade se abriga e que o primeiro não pode ser entendido sem a segunda (Gadamer, 1977). 
Em grande parte a compreensão transforma-se num ser que não está mais adiante, passível, aguardando sua finalização, mas situa-se na condução e na perspectiva de um ser projeto. Em parte, um projeto predisposto, preconcebido, mas, também, um projeto indeterminado, incompleto, encontrando na incompletude e na infinitude sua verdadeira identidade. Esse encurtamento do ser ao espaço do interminável, por um lado, ainda não pode ser captado por nenhuma estrutura técnica de comunicação, por outro lado, sempre teve seu espaço garantido na experiência estética.

O instrumento digital reduz, constrói e destrói, exatamente porque vai às coisas mesmas. Faneron é a expressão peirceana à atuação do real na semiótica, o real assumindo sua condição de materialidade. Tudo o que colabora para a representação é faneron. É o império do signo numa estrutura analítica. Justamente esse movimento de representação, que oferece à mente uma leitura do exterior, faz do representado, comunicação; do comunicado, significação; e da idéia resultante, o interpretante. O fruto da representação é uma representação que a primeira representação interpreta. Com base peirceana entendemos que todo processo de comunicação se apresenta como uma série sem fim de representações, cada uma delas, concomitantemente, representando a anterior e projetando a próximas.

Na hipermídia como experiência estética, a significação de uma representação é sempre outra representação. Esse caminho tem a potencialidade de revelar tanto uma projeção quanto uma rejeição infinitas.

Finalmente, o interpretante é outra representação a cujas mãos passa o facho da verdade; e como representação também possui interpretante. Aí está uma nova série infinita! (Peirce, 1967: 56).

Há certo desdobramento do signo - pensamento que representa todo o objeto na perspectiva, à medida que ele passa a pensar no interior dessa própria perspectiva. É a imediatez da constécnica peirceana, ou seja, o pensamento pensado no pensamento subseqüente a quem serve o signo. Rede de signos é como devemos entender uma produção hipermídia que nos ofereça navegação não-linear e que evite nos abandonar à sorte do caminho. Ser é igual a linguagem. Não há como instrumentalizar os signos para entendermos sua essência, assim como não podemos pensar sem signos. Nenhum pensamento precede o império dos signos, pois é sempre 
o resultado de uma semiose ilimitada, tal como na rede lacaniana de significantes. $\mathrm{O}$ sentido próprio da constécnica está justamente no fato de esta pertencer ao signo; está à mercê desse e lhe dá consistência.

\begin{abstract}
Uma vez que o homem só pensa por signos e outros símbolos exteriores, esses poderiam retorquir: 'Tudo o que você diz aprendeu-o conosco, e sempre precisará de uma palavra como interpretante de teu pensamento'. De fato, os homens e as palavras educam-se mutuamente; cada aumento de informação humana envolve e é envolvido por um aumento de informações das palavras. Não há elemento na constécnica que não tenha correspondente na palavra. É por esse caminho que devemos entender que o signo é o próprio homem: 'A minha linguagem, assim, é a soma de mim próprio; porque o homem é o pensamento. (Peirce, 1967: 58)
\end{abstract}

Em síntese, a hipermídia deve atuar como uma comunidade de comunicação, simulando o mundo da linguagem partilhada que a pressupõe.

Esse é o ponto fulcral: a possibilidade de construção de um mundo que ofereça a demonstração dos contextos cotidianos. Por um lado, o mundo das tradições midiáticas analógicas e analíticas, pode ser apreendido por essas mídias digitais tecnofágicas, por outro lado, é justamente a possibilidade de construção desse mundo que revela o nascimento de uma técnica. Não a expressão de uma nova técnica, mas um processo de multiplicação de horizontes pelo qual podemos nos situar tecnicamente no limiar de novas maneiras de conhecimento. A essência dessa nova maneira de conhecer, se localiza não somente no fato de ela comportar uma relação com tudo que já está aí, de uma maneira ou de outra revelado, mas também porque comporta sempre uma possibilidade estética que desvela tanto sua identidade quanto seu próprio desvelamento. Porém, tal desvelamento só pode emergir à medida que o mundo das tecnologias digitais se encontra com o dia-a-dia daquele que the pretende usar. De nada adianta ficarmos numa contemplação melancólica frente ao fenômeno, como costumam, por vezes, fazer alguns críticos das comunicações. O fenômeno atual das ferramentas e o mundo da utensilagem digital não está aí para contemplação, seja lá qual for a intenção, acadêmica ou estética. É uma típica tecnologia que para ser reconstruída e ou desmistificada, só podemos fazê-lo imersos no seu mundo. Instrumento, ferramenta, utensílio, máquina, objeto, coisa, plástico e energia, eis sua essência cóisica que situa-se muito aquém de suas potencialidades, já que essas não estão, primordialmente, localizadas em seu estar-no-mundo. 
É em nosso comércio com o utensílio que nós realizamos unicamente conhecimento com ele. Longe de possuirmos um saber das coisas anterior ao seu uso, é, ao contrário, a utilização enquanto tal que constitui aqui o modo de tomada do conhecimento primário e adequado, um modo primário e apropriado de descoberta do ente intra mundano. Da mesma forma, não é refletindo sobre a natureza que a desvelamos na potencialidade de seu reino, mas combatendo-a, protegendo-nos dela e tornando nos mestres frente a ela. (Heidegger, 2001: 98).

Tanto a produção de uma compreensão usando a técnica como horizonte, quanto a compreensão que se torna fruto desse caminho, atravessam por momentos imprecisos de pré-compreensão que, estes, sim, não se apresentam a nós de forma explícita. No entanto, é justamente esse mundo de pré-compreensões que dialoga prioritariamente no uso da técnica digital.

Portanto, as discussões em torno do encontro da técnica com o modo de ser da compreensão, não podem deixar de lado este encontro entre a técnica como horizonte, a experiência estética e a hipermídia.

\section{REFERÊNCIAS BIBLIOGRÁFICAS}

AUERBACH, Eric. Introduction aux études de philologie romane. Frankfurt:

Vittorio Klostermann, 1970

BAIRON, Sérgio \& PETRY, Luis Carlos. Hipermídia, psicanálise e história da cultura. São Paulo/Caxias do Sul: Educs \& Ed. Mackenzie, 2000

BAIRON, Sérgio \& RIBEIRO, José S. Antropologia Visual e Hipermédia. Porto: Afrontamento, 2007

BENJAMIN, Walter. Einbahnstrasse. Frankfurt: Suhrkamp, 1977

BOLTER, Jay David. Writing space: the computer, hypertext, and the history of writing. Hillsdela: N.J. Lawrence Erlbaum, 1991

BURDEA, Grigore \& Coiffet, Philippe. Tecnologías de la realidad virtual.

Barcelona: Paidós, 1996

CALABRESE, E. La era neobarroca, Madridd: Cátedra, 1989

DARLEY, Andrew. Visual digital culture. London: Routledge, 2002

GADAMER, Hans Georg. Der Anfang des Wissens. Berlin: Reclam, Ditzingen, 1999 
A técnica como horizonte, a experiência estética e a hipermídia

1988

Die Atualität des Schöen: Kunst als Spiel, Symbol und fest.

Stuttgart: Philipp Reclam, 1977

HANSEN, Mark. Embodying Technesis. Michigan, Michigan Press, 2000 New philosophy for new media. Cambridge, London, MIT Press, 2004

HEIDEGGER, Martin. Der Ursprung des Kunstwerkes. Vittorio Frankfurt:

Klostermann GmbH, 1952

- Die Frage nach dem Ding. Zu Kants Lehre von den

transzendentalen Grundsätzen. Tübingen: Niemeyer, 1985 . Sein und Zeit. Thomas Rentsch: Akademie-Verlag, 2001

HEIM, Michael. Electric language, New York: Oxford University Press, 1992 .Virtual realism. New York, Oxford University Press, 1998

LANDOW, George \& Delany, Paul. Hypermedia and literary studies. Cambridge/ Londres, MIT Press, 1991

LÉVY, Pierre. Cibercultura. São Paulo: Editora 34, 1999

MACKAY, Hugh \& O'sullivan, Tim. The media reader: continuity and ransformation. London: Sage Publications, 1999

MCLUHAN, Eric. Electric language. New York: St. Martin's Press, 1998

HILLIS, Ken. Digital sensations. Minneapolis: University of Minnesota Press, 1999

MANDELBROT, Benoit. The fractal geometry of nature. Nova York: W.H.

Freeman and Company, 1977

PEIRCE, Charles S. Semiótica. São Paulo: Perspectiva, 1987

OLSON, David. O mundo no papel. São Paulo: Ática, 1998

QUÉAU, Philippe. Lo virtual - virtudes e vértigos. Barcelona: Paidós, 1996

SANTAELLA, Lucia. Produção de linguagem e ideologias. São Paulo: Cortez, 1998 . Matrizes da linguagem e pensamento. Sonora Verbal Visual. São

Paulo: Iluminuras, 2001

THAMES \& HUDOSN, A. The Arcimboldo effect. Milão: Gruppo Editoriale Fabbri, Bompiani, Sonzogno, 1987

TURKE, Sherry. Life on the screen. New York: Touchstone, 1997

WITTGENSTEIN, Ludwig. Investigações filosóficas. Lisboa: Calouste Gulbenkien, 1989 O caderno azul. Lisboa: Edições 70, 1987 
A técnica como horizonte, a experiência estética e a hipermídia de Sergio Bairon

O Livro Castanho. Lisboa, Edições 70, 1984

Artigo recebido: 09/12/2011

Artigo aprovado: 20/12/2011 